\title{
OPTIMASI PENDISTRIBUSIAN TANAH DENGAN MENGGUNAKAN METODE LINEAR PROGRAMMING
}

\author{
Gaston Sudjaja $^{1}$ dan Iwan B. Santoso ${ }^{2}$ \\ ${ }^{1}$ Program Studi Sarjana Teknik Sipil, Universitas Tarumanagara, Jl. Letjen S. Parman No.1 Jakarta \\ Email: gastonsudjaja@yahoo.co.id \\ ${ }_{2}^{2}$ Program Studi Sarjana Teknik Sipil, Universitas Tarumanagara, Jl. Letjen S Parman No.1 Jakarta \\ Email:iwsantoso@hotmail.com
}

\begin{abstract}
ABSTRAK
Pembangunan jalan merupakan kebutuhan yang sangat vital sebagai pendukung utama dinamika dan aktivitas ekonomi. Salah satu faktor yang harus dikendalikan dalam pembangunan suatu jalan adalah masalah biaya konstruksi. Pada umumnya diperlukan dana yang besar dalam pembangunan jalan, namun dana yang disediakan untuk keperluan tersebut sangat terbatas. Salah satu cara untuk meminimalkan biaya pembangunan suatu jalan adalah meminimumkan biaya pendistribusian tanah. Pendistribusian tanah pada umumnya berkaitan dengan pemilihan alat - alat berat yang digunakan dan jarak pendistribusian tanah. Dalam penelitian ini digunakan metode linear programming untuk memudahkan dalam menentukan volume tanah yang akan dipindahkan dari suatu tempat ke tempat lain. Linear programming terdiri dari decision variabel, objective function, dan constraint. Dari penelitian ini diperoleh hasil optimasi volume pendistribusian tanah dan biaya yang minimum.
\end{abstract}

Kata kunci: Pendistribusian Tanah, Alat Berat, Linear Programming

\section{PENDAHULUAN}

\section{Latar Belakang}

Pekerjaan konstruksi merupakan keseluruhan atau sebagian kegiatan perencanaan untuk membangun sarana maupun prasarana dalam infrastruktur pembangunan. Pembangunan yang dimaksud adalah gedung, jembatan, jalan, dan pembangunan lainnya. Jalan merupakan infrastruktur yang menghubungkan satu daerah dengan daerah yang lain yang sangat penting dalam sistem pelayanan masyarakat (Wirahadikusumah, 2007). Kini pembangunan jalan di Indonesia sedang dilakukan secara besar - besaran karena pertumbuhan penduduk di Indonesia semakin meningkat, sedangkan kapasitas jalan yang ada sekarang ini bisa dikatakan tidak sesuai dengan kebutuhan penduduk. Hal ini disebabkan karena jumlah kendaraan yang ada di Indonesia semakin banyak.

Salah satu faktor yang harus dikendalikan dalam pembangunan suatu jalan adalah masalah biaya. Pada umumnya diperlukan dana yang besar dalam pembangunan jalan, padahal dana yang disediakan untuk keperluan tersebut sangat terbatas. Oleh sebab itu penggunaan dana yang tersedia harus dimanfaatkan dengan sebaik - baiknya. Secara umum sasaran yang harus dicapai untuk menimalkan biaya pembangunan suatu jalan adalah pekerjaan tanah. Pekerjaan tanah di sini meliputi pekerjaan galian, timbunan, pengangkutan, dan pemadatan tanah. Pendistribusian tanah pada umumnya berkaitan dengan pemilihan alat - alat berat yang digunakan, jarak pendistribusian tanah dari suatu lokasi ke lokasi lain. Untuk menyelesaian suatu pekerjaan atau bagian pekerjaan konstruksi diperlukan pemilihan alat dimana pemilihan alat - alat berat tergantung pada karakteristik masing- masing alat dan kondisi medan. Hal ini diperlukan agar alat tersebut dapat bekerja secara maksimal sehingga pekerjaan dapat diselesaikan tepat waktu dengan biaya sehemat mungkin. Selain itu pelaksanaan suatu proyek konstruksi juga selalu terdapat kendala-kendala, baik kendala yang sudah diperhitungkan maupun di luar perhitungan perencana. Tujuan dari pemilihan alat - alat berat tersebut adalah untuk memudahkan manusia dalam mengerjakan pekerjaannya sehingga hasil yang diharapkan dapat tercapai dengan lebih mudah pada waktu yang relatif lebih singkat. Manajemen alat berat sangat diperlukan, sehingga dapat menunjang kelancaran dari pekerjaan tersebut.

Pada proyek pembangunan jalan, umumnya masalah pendistribusian tanah didasarkan atas faktor pengalaman dari perencana atau dibantu dengan diagram mass haul. Jika ditinjau dari cara tersebut maka tidak ada kepastian bahwa hasil yang diperoleh akan pasti mengenai besarnya volume pendistribusian tanah. Untuk itu diperlukan suatu metode yang digunakan untuk menyelesaikan permasalahan pendistribusian tanah untuk mengetahui jumlah dan arah pendistribusian tanah yang baik dengan biaya yang minimum. Metode yang digunakan adalah metode linear programming, linear programming merupakan sebuah metode matematika untuk memecahkan permasalah dalam berbagai bidang untuk mencapai suatu tujuan yang optimal. Tujuan optimal yang dimaksud adalah dengan sumber 
daya yang terbatas dapat membantu perencana untuk memperoleh biaya yang minimum dengan keuntungan maksimum. Maka dari itu, peneliti tertarik untuk melakukan penelitian terhadap permasalahan yang ada.

\section{Identifikasi Masalah}

Berdasarkan latar belakang di atas, masalah yang akan dijadikan bahan penelitian yaitu biaya pendistribusian tanah untuk pembuatan jalan yang mahal dan ketidaktepatan dalam pemilihan alat berat yang digunakan.

\section{Rumusan Masalah}

Berdasarkan uraian yang dituliskan di atas, terdapat masalah yang perlu untuk dibahas yaitu bagaimana perencanaan volume pendistribusian tanah cut and fill dan meminimalkan biaya pendistribusian tanah dengan menggunakan metode linear programming.

\section{Tujuan Penelitian}

1. Mengkaji perencanaan volume pendis-tribusian tanah cut and fill dan mengetahui biaya minimum untuk pendistribusian tanah dengan meng-gunakan metode linear programming.

2. Menganalisis hasil optimasi volume pendistribusian tanah cut and fill.

\section{Batasan Penelitian}

1. Penelitian yang dilakukan adalah jumlah volume cut and fill untuk pembangunan jalan sejauh $5 \mathrm{~km}$.

2. Data yang didapat untuk penelitian merupakan data yang diperoleh dari proyek X di Karawang.

3. Metode perhitungan yang digunakan adalah linear programming dengan menggunakan program Lingo.

\section{TINJAUAN PUSTAKA}

\section{Tanah}

Menurut Das (1995) tanah diartikan sebagai material yang terdiri dari agregat mineral - mineral padat yang tidak tersementasi (terikat secara kimia) satu sama lain dan dari bahan-bahan organik telah melapuk (yang berpartikel padat) disertai dengan zat cair dan gas yang mengisi ruangruang kosong diantara partikel-partikel padat tersebut.

Menurut Bowles (1989) istilah pasir, lempung, lanau, atau lumpur digunakan untuk menggambarkan ukuran partikel pada batas ukuran butiran yang telah ditentukan. Akan tetapi, istilah yang sama juga digunakan untuk menggambarkan sifat tanah yang khusus. Sebagai contoh, lempung adalah jenis tanah yang bersifat kohesif dan plastis, sedang pasir digambarkan sebagai tanah yang tidak kohesif dan tidak plastis.

Keadaan material yang dapat mempengaruhi volume tanah yang dijumpai dalam usaha pendistribusian tanah menurut Rochmanhadi (1990) yaitu:

1. Keadaan asli (Bank Measure $=\mathrm{BM})$

Keadaan asli adalah keadaaan material sebelum dilakukan pengerjaan atau masih sesuai dengan ukuran alam, digunakan sebagai dasar perhitungan jumlah pemindahan.

2. Keadaan lepas (Loose Measure $=\mathrm{LM})$

Keadaan lepas adalah keadaan tanah setelah diadakan pengerjaan, misalnya tanah yang terdapat di depan dozer blade, di atas dump truck, di dalam bucket, dan sebagainya. Hal ini disebabkan karena adanya penambahan rongga udara di antara butiran - butiran tanah, sehingga volume menjadi lebih besar.

3. Keadaan padat (Compacted Measure)

Keadaan padat adalah keadaan material setelah ditimbun dan dilakukan pemadatan. Perubahan volume terjadi karena adanya penyusutan rongga udara di antara partikel - partikel tanah tersebut. Dengan demikian volume tanah akan berkurang, sedangkan beratnya tetap. Volume tanah setelah diadakan pemadatan, mungkin lebih besar atau mungkin juga lebih kecil, hal ini tergantung dari usaha pemadatan yang dilakukan.

\section{Analisis Pendistribusian Tanah}

Menurut Rochmanhadi (1990) dengan hanya mengetahui besarnya volume tanah baik volume cut, fill, borrow pit, dan landfill saja, tidak cukup memberikan informasi untuk melaksanakan suatu pendistribusian tanah. Maka diperlukan juga untuk mengetahui distribusi pemindahan tanah yang meliputi jumlah, arah, dan jarak angkut dalam perencanaan. Diusahakan supaya jarak angkut yang terjadi di lapangan tidak melebihi jarak angkut ekonomis alat alat berat yang digunakan. Jarak ekonomis berkaitan dengan free haul dan over haul dari material yang diangkut. 
Biasanya dalam suatu kontrak memuat perjanjian yang memberikan pembayaran tambahan untuk angkutan material jika melebihi jarak angkut tertentu (free haul). Bila pengangkutan melebihi batas free haul maka disebut sebagai over haul. Batasan untuk mencari jarak angkut ekonomis sama dengan batas dari free haul ditambah dengan hasil bagi yang didapat dari harga satuan untuk borrow lalu dibagi dengan harga satuan untuk over haul.

Dalam pelaksanaan pekerjaan pendistribusian tanah, biasanya dilakukan pengikisan lapisan tanah atas (stripping) terlebih dahulu untuk menghilangkan lapisan atas tanah yang memiliki sifat - sifat yang dapat merugikan kondisi jalan yang akan dibuat di atasnya. Pada umumnya dilihat dari potongan memanjang kontur asli pada sumbu jalan tidak sesuai dengan persyaratan geometris dari jalan yang direncanakan maka dilakukan cut and fill. Diusahakan agar tanah pada lokasi cut dapat diberikan pada lokasi fill. Untuk melaksanakan cut and fill, harus dilakukan pengetesan terhadap mutu, jenis, dan karakteristik tanah. Dari hasil pengetesan dapat diketahui tanah tersebut dapat digunakan atau tidak. Jika tanah pada lokasi cut tidak dapat diberikan pada lokasi fill, maka tanah tersebut harus dibuang ke tempat pembuangan tanah (landfill). Letak landfill sudah harus ditentukan terlebih dahulu berdasarkan pihak - pihak yang bersangkutan. Untuk pengisian tanah pada lokasi fill dapat menggunakan tanah yang berasal dari lokasi cut yang mempunyai sifat, jenis, dan karakteristik tanah yang sama maupun dapat menggunakan tanah yang berasal dari borrow pit yang sesuai persyaratan.

Menurut Rochmanhadi (1990) Terdapat beberapa cara untuk menyelesaikan analisis distribusi pemindahan tanah, antara lain:

\title{
1. Cara mencoba coba
}

Dalam suatu proyek yang tidak terlalu besar, jumlah volume cut dan fill relatif kecil sehingga cara mencoba coba merupakan cara yang efektif dan efisien untuk dilakukan dan ditambah juga faktor pengalaman dari perencana dapat memberikan hasil yang cukup memuaskan untuk melakukan distribusi pemindahan tanah.

2. Cara titik keseimbangan

Pada dasarnya titik - titik keseimbangan merupakan titik- titik pada garis keseimbangan yang ditarik secara horizontal pada potongan memanjang jalan atau pada diagram mass haul.

\begin{abstract}
Alat - Alat Berat
Menurut Rochmanhadi (1992) alat berat merupakan mesin berukuran besar yang didesain untuk melaksanakan fungsi konstruksi seperti pengerjaan tanah (earthworking) dan memindahkan bahan bangunan. Alat berat umumnya terdiri atas lima komponen, yaitu implemen, alat traksi, struktur, sumber tenaga dan transmisinya (power train), serta sistem kendali. Sesuai dengan namanya, alat berat biasanya digunakan untuk membantu manusia mengerjakan pekerjaan yang berat seperti pembuatan danau, pembuatan jalan, dan sebagainya. Penggunaan alat berat yang kurang tepat dengan kondisi dan situasi lapangan pekerjaan akan berpengaruh berupa kerugian, antara lain rendahnya produksi, tidak tercapainya jadwal atau target yang telah ditentukan atau kerugian biaya perbaikan yang tidak semestinya.
\end{abstract}

\section{Linear Programming}

Chase, et al (2001) menyatakan program linear merupakan suatu metode pemecahan optimalisasi secara matematik melalui pengalokasian sumber daya yang terbatas diantara tipe penggunaan yang bersaing. Optimalisasi tersebut dapat berupa maksimalisasi kontribusi dan dapat pula merupakan minimalisasi biaya. Secara umum program linear dapat diartikan sebagai sebuah metode matematik yang diper-gunakan untuk pemecahan optimum sebuah fungsi tujuan linear melalui pengalokasian sumber daya yang terbatas yang dimiliki sebuah organisasi atau perusahaan.

Menurut Todd (2002) model linear programming merupakan bentuk atau susunan dalam menyajikan masalah masalah yang akan dipecahkan dengan teknik linear programming. Dalam model linear programming dikenal variable keputusan (decision variable), fungsi tujuan (objective fungtion), dan fungsi batasan (constraint fungtion). Variabel keputusan adalah variable yang menguraikan secara lengkap keputusan - keputusan yang akan dibuat, dinyatakan dengan X1, X2, X3, X4, ..., Xn. Fungsi tujuan adalah fungsi yang menggambarkan tujuan / sasaran didalam permasalahan linear programming yang berkaitan dengan pengaturan secara optimal sumber daya, untuk memperoleh keuntungan maksimal atau biaya minimal. Pada umumnya nilai objective function yang akan dimaksimumkan atau diminimumkan dinyatakan dengan $\mathrm{Z}$, sedangkan fungsi batasan merupakan bentuk penyajian secara matematis batasan kapasitas yang tersedia yang akan dialokasikan secara optimal keberbagai kegiatan.

\section{METODOLOGI PENELIITIAN}

\section{Kerangka Berpikir}


Seluruh langkah kerja yang akan dilakukan dalam penelitian ini dapat dilihat melalui kerangka berpikir yang dapat dilihat melalui gambar 1.

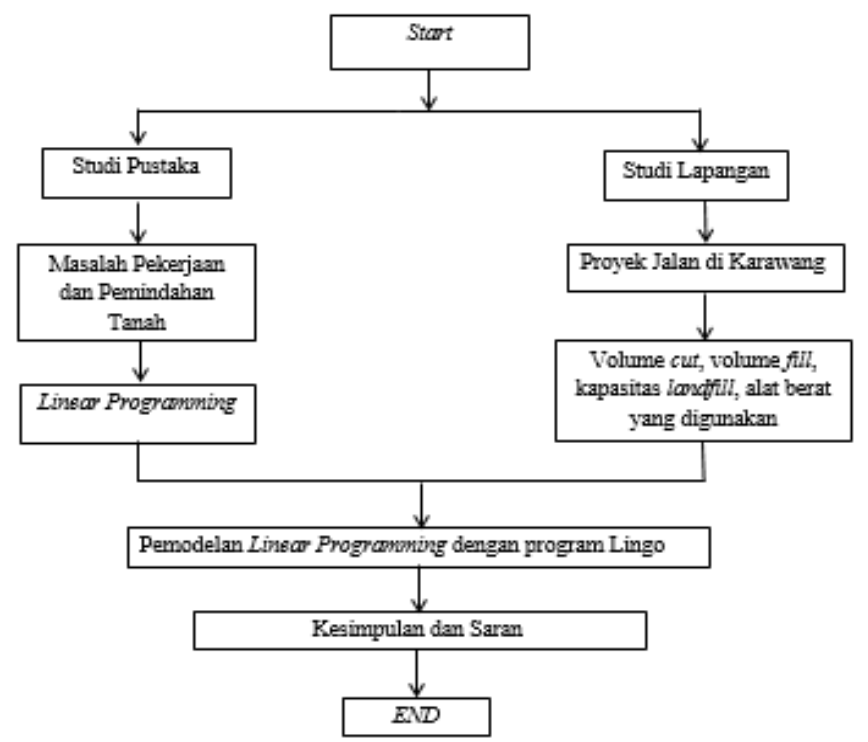

Gambar 1 Kerangka Berpikir

\section{Pengolahan Data}

Setelah mengumpulkan data yang akan diolah dengan menggunakan metode linear programming, tahap - tahap yang harus dilakukan dalam pengolahan data dengan metode ini adalah sebagai berikut:

1. Melakukan penyesuaian mengenai data - data yang didapat dengan data yang diperlukan untuk analisis.

2. Menentukan variabel keputusan (decision variable) dan dinyatakan dalam bentuk simbol.

3. Menentukan fungsi tujuan (objection function) yang diinginkan (maksimalisasi atau minimalisasi) berdasarkan variabel keputusan.

4. Menentukan batasan masalah (constraint) yang terdapat dalam data dan menuliskan ke dalam bentuk persamaan atau pertidaksamaan berdasarkan decision variable yang ada.

5. Melakukan pengolahan data menggunakan metode linear programming dengan bantuan program Lingo.

6. Membandingkan hasil yang didapat dari optimasi menggunakan linear programming berdasarkan data aktual yang didapat dari perusahaan untuk menunjukkan perhitungan mana yang lebih baik.

\section{HASIL DAN PEMBAHASAN}

\section{Perhitungan Biaya Operasional Alat Berat}

Perhitungan biaya untuk alat berat yang dimiliki sendiri adalah sebagai berikut:

1. Excavator

Perhitungan biaya satuan excavator terdiri dari biaya pemilikan alat ditambah biaya operasi.

a. Biaya pemilikan alat

Harga alat: Rp 685.000.000, -

Perkiraan umur alat: 4 tahun $\rightarrow 14400$ jam

Biaya pemilikan $/ \mathrm{jam}=685000000 / 14400 \mathrm{jam}$

$=47.569,4444 \rightarrow 48.000$

b. Biaya operasi

Horse Power $=140$

Harga bahan bakar solar $=$ Rp 5150, -

Biaya operasi / jam bahan bakar

$=\mathrm{F} \times 0.2$ (solar) $\mathrm{x} \mathrm{h} \times \mathrm{PK}$

$=0.7 \times 0.2 \times 5150 \times 140$

$=100.940 \rightarrow 101.000$

Biaya operasi perbaikan $=($ faktor perbaikan $\mathrm{x}$ harga mesin $) /$ umur alat $=(1.1 \mathrm{x} 685.000 .000) / 14400$

$=52.326,3889 \rightarrow 52.500$

Maka total biaya $=\operatorname{Rp} 48.000,-+\operatorname{Rp} 101.000,-+R p 52.500,-$ 
$=\operatorname{Rp} 201.500,-/$ jam

Produktivitas alat $=67.26 \mathrm{~m}^{3} / \mathrm{jam}$

Jadi biaya satuan alat excavator $=201500 / 67.26$

$=\operatorname{Rp} 2995.8371 \rightarrow \operatorname{Rp} 3000,-/ \mathrm{m}^{3}$

2. Bulldozer

Perhitungan biaya satuan bulldozer terdiri dari biaya pemilikan alat ditambah biaya operasi.

a.

Harga alat: Rp 1.000.000.000, -

Perkiraan umur alat: 4 tahun $\rightarrow 14400$ jam

Biaya pemilikan $/$ jam $=1000000000 / 14400$ jam

$=69.444,4444 \rightarrow 70.000$

b. Biaya operasi

Horse Power $=205$

Harga bahan bakar solar = Rp 5150, -

Biaya operasi / jam bahan bakar

$=\mathrm{F} \times 0.2$ (solar) $\mathrm{xh} \times \mathrm{PK}$

$=0.7 \times 0.2 \times 5150 \times 205$

$=147.805 \rightarrow 148.000$

Biaya operasi perbaikan $=($ faktor perbaikan $\mathrm{x}$ harga mesin $) /$ umur alat $=(1.1 \mathrm{x} 1.000 .000 .000) / 14400$

$=76.388,8889 \rightarrow 76.500$

Maka total biaya $=\operatorname{Rp} 70.000,-+\operatorname{Rp} 148.000,-+\operatorname{Rp} 76.500,-$

$=\operatorname{Rp} 294.500,-$ / jam

Produktivitas alat $=54.46 \mathrm{~m}^{3} / \mathrm{jam}$

Jadi biaya satuan alat bulldozer $=294500 / 54.46$

$=\operatorname{Rp} 5407,6386 \rightarrow \operatorname{Rp} 5500,-/ \mathrm{m}^{3}$

3. Vibro Roller

Perhitungan biaya satuan vibro roller terdiri dari biaya pemilikan alat ditambah biaya operasi.

a. Biaya pemilikan alat

Harga alat: Rp 350.000.000, -

Perkiraan umur alat: 2 tahun $\rightarrow 7200$ jam

Biaya pemilikan $/ \mathrm{jam}=350000000 / 7200 \mathrm{jam}$

$=48611,1111 \rightarrow 49.000$

b. Biaya operasi

Horse Power $=110$

Harga bahan bakar solar = Rp 5150, -

Biaya operasi / jam bahan bakar

$=\mathrm{F} \times 0.2$ (solar) $\mathrm{x} \mathrm{h} \times \mathrm{PK}$

$=0.7 \times 0.2 \times 5150 \times 110$

$=79.310 \rightarrow 79.500$

Biaya operasi perbaikan $=($ faktor perbaikan $\mathrm{x}$ harga mesin $) /$ umur alat

$=(1.1 \times 350.000 .000) / 7200$

$=53.472,2222 \rightarrow 53.500$

Maka total biaya $=\operatorname{Rp} 49.000,-+\operatorname{Rp} 79.500,-+\operatorname{Rp} 53.500,-$

$=\operatorname{Rp} 182.000,-/$ jam

Produktivitas alat $=106.5 \mathrm{~m}^{3} / \mathrm{jam}$

Jadi biaya satuan alat vibro roller $=182000 / 106.5$

$=\mathrm{Rp} 1708,9202 \rightarrow \mathrm{Rp} 1800,-/ \mathrm{m}^{3}$

4. Dump truck

Perhitungan biaya satuan dump truck terdiri dari biaya pemilikan alat ditambah biaya operasi.

a. Biaya pemilikan alat

Harga alat: Rp 500.000.000, -

Perkiraan umur alat: 4 tahun $\rightarrow 14400$ jam

Biaya pemilikan $/$ jam $=500000000 / 14400$ jam

$=34.722,2222 \rightarrow 35.000$

b. Biaya operasi

Horse Power $=245$

Harga bahan bakar solar = Rp 5150, -

Biaya operasi / jam bahan bakar

$=\mathrm{F} \times 0.2$ (solar) $\mathrm{xh} \times \mathrm{PK}$ 


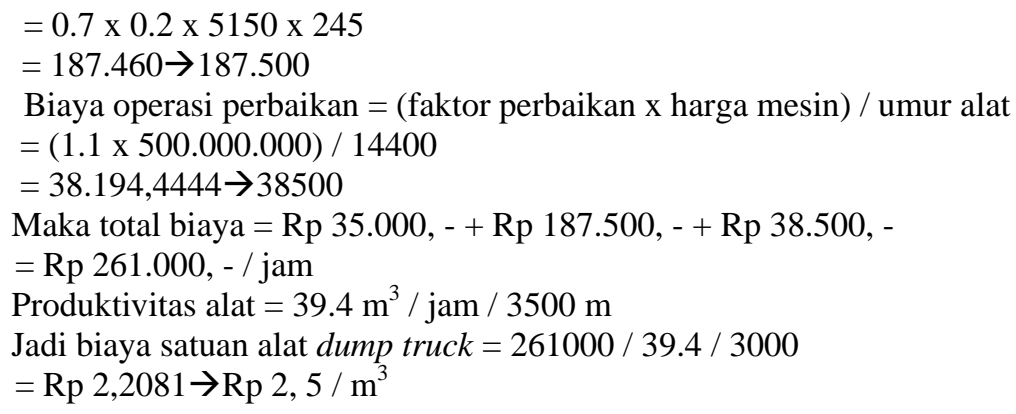

\section{Perhitungan Biaya Satuan Pekerjaan Pendistribusian Tanah}

Setelah menghitung biaya operasional alat berat, selanjutnya menghitung biaya satuan pekerjaan yang terdiri dari:

1. Biaya satuan dari pekerjaan excavation termasuk loading

Biaya satuan dari excavator + biaya satuan dari bulldozer

$=\operatorname{Rp} 3000,-+\operatorname{Rp} 5500,-$

$=\operatorname{Rp} 8500,-/ \mathrm{m}^{3}$

2. Biaya satuan dari pekerjaan hauling

Biaya satuan dari dump truck $=\operatorname{Rp} 2,5 / \mathrm{m}^{3} / \mathrm{m}$

3. Biaya satuan dari pekerjaan embankment termasuk placement dan compaction

Biaya satuan dari excavator + biaya satuan dari vibro roller

$=\operatorname{Rp} 3000,-+\operatorname{Rp} 1800,-$

$=\operatorname{Rp} 4800,-/ \mathrm{m}^{3}$

Maka untuk menghitung biaya satuan pekerjaan pendistrbusian tanah dari lokasi cut ke lokasi fill, dari lokasi cut ke lokasi landfill, dan dari lokasi borrow pit ke lokasi fill dapat menggunakan rumus sebagai berikut:

$\mathrm{C}(\mathrm{i}, \mathrm{j})=\mathrm{Ue}+\mathrm{Si}(\mathrm{Uh} * \mathrm{dij}+\mathrm{Uc})$

Keterangan:

$\mathrm{C}(\mathrm{i}, \mathrm{j})=$ biaya pendistri-busian tanah dari lokasi i ke lokasi $\mathrm{j}$

$\mathrm{Ue} \quad=$ biaya satuan dari pekerjaan excavation termasuk loading

$\mathrm{Si} \quad=1.3$ (faktor swell tanah akibat pengakutan)

Uh = biaya satuan dari pekerjaan hauling

dij $\quad=$ jarak pendstribusian tanah dari lokasi i ke lokasi $\mathrm{j}$

Uc = biaya satuan dari pekerjaan embankment termasuk placement dan compaction

\section{Pemodelan Linear Programming}

Pemodelan optimasi penditribusian tanah dalam bentuk linear programming adalah sebagai berikut:

1. Decision Variable

Decision variable yang digunakan untuk pendistribusian tanah dari lokasi cut 9, 14, 16, 17, 22, 28, dan 32 ke lokasi fill (sebagai contoh pendistribusian dari lokasi cut 9):

a. $\mathrm{x}(9,1)=$ volume pendistribusian tanah dari lokasi 9 ke lokasi $1\left(\mathrm{~m}^{3}\right)$

b. $x(9,2)=$ volume pendistribusian tanah dari lokasi 9 ke lokasi $2\left(\mathrm{~m}^{3}\right)$

c. $x(9,3)=$ volume pendistribusian tanah dari lokasi 9 ke lokasi $3\left(\mathrm{~m}^{3}\right)$

d. $x(9,4)=$ volume pendistribusian tanah dari lokasi 9 ke lokasi $4\left(\mathrm{~m}^{3}\right)$

e. $x(9,5)=$ volume pendistribusian tanah dari lokasi 9 ke lokasi $5\left(\mathrm{~m}^{3}\right)$

f. $x(9,6)=$ volume pendistribusian tanah dari lokasi 9 ke lokasi $6\left(\mathrm{~m}^{3}\right)$

g. $x(9,8)=$ volume pendistribusian tanah dari lokasi 9 ke lokasi $8\left(\mathrm{~m}^{3}\right)$

h. $x(9,11)=$ volume pendistribusian tanah dari lokasi 9 ke lokasi $11\left(\mathrm{~m}^{3}\right)$

i. $x(9,13)=$ volume pendistribusian tanah dari lokasi 9 ke lokasi $13\left(\mathrm{~m}^{3}\right)$

j. $x(9,15)=$ volume pendistribusian tanah dari lokasi 9 ke lokasi $15\left(\mathrm{~m}^{3}\right)$

k. $x(9,18)=$ volume pendistribusian tanah dari lokasi 9 ke lokasi $18\left(\mathrm{~m}^{3}\right)$

1. $\mathrm{x}(9,20)=$ volume pendistribusian tanah dari lokasi 9 ke lokasi $20\left(\mathrm{~m}^{3}\right)$

m. $x(9,21)=$ volume pendistribusian tanah dari lokasi 9 ke lokasi $21\left(\mathrm{~m}^{3}\right)$

n. $x(9,23)=$ volume pendistribusian tanah dari lokasi 9 ke lokasi $23\left(\mathrm{~m}^{3}\right)$

o. $x(9,24)=$ volume pendistribusian tanah dari lokasi 9 ke lokasi $24\left(\mathrm{~m}^{3}\right)$

p. $x(9,26)=$ volume pendistribusian tanah dari lokasi 9 ke lokasi $26\left(\mathrm{~m}^{3}\right)$ 
q. $x(9,27)=$ volume pendistribusian tanah dari lokasi 9 ke lokasi $27\left(\mathrm{~m}^{3}\right)$ r. $x(9,29)=$ volume pendistribusian tanah dari lokasi 9 ke lokasi $29\left(\mathrm{~m}^{3}\right)$ s. $x(9,30)=$ volume pendistribusian tanah dari lokasi 9 ke lokasi $30\left(\mathrm{~m}^{3}\right)$ t. $x(9,31)=$ volume pendistribusian tanah dari lokasi 9 ke lokasi $31\left(\mathrm{~m}^{3}\right)$ u. $x(9,33)=$ volume pendistribusian tanah dari lokasi 9 ke lokasi $33\left(\mathrm{~m}^{3}\right)$ v. $\mathrm{x}(9,34)=$ volume pendistribusian tanah dari lokasi 9 ke lokasi $34\left(\mathrm{~m}^{3}\right)$ w. $\mathrm{xD}(9, \mathrm{~K} 1)=$ volume pendistribusian tanah dari lokasi 9 ke lokasi $\mathrm{K} 1\left(\mathrm{~m}^{3}\right)$ $\mathrm{x} . \mathrm{xD}(9, \mathrm{~K} 2)=$ volume pendistribusian tanah dari lokasi 9 ke lokasi $\mathrm{K} 2\left(\mathrm{~m}^{3}\right)$ $\mathrm{y} \cdot \mathrm{xD}(9, \mathrm{~K} 3)=$ volume pendistribusian tanah dari lokasi 9 ke lokasi $\mathrm{K} 3\left(\mathrm{~m}^{3}\right)$

Decision variable yang digunakan untuk pendistribusian tanah dari lokasi cut 7, 10, 12, 19, dan 25 ke lokasi landfill (sebagai contoh pendistribusian dari lokasi cut 7):

a. $\mathrm{xD}(7, \mathrm{~K} 1)=$ volume pendistribusian tanah dari lokasi 7 ke lokasi $\mathrm{K} 1\left(\mathrm{~m}^{3}\right)$

b. $\mathrm{xD}(7, \mathrm{~K} 2)=$ volume pendistribusian tanah dari lokasi 7 ke lokasi $\mathrm{K} 2\left(\mathrm{~m}^{3}\right)$

c. $\mathrm{xD}(7, \mathrm{~K} 3)=$ volume pendistribusian tanah dari lokasi 7 ke lokasi $\mathrm{K} 3\left(\mathrm{~m}^{3}\right)$

Decision variable yang digunakan untuk pendistribusian tanah dari lokasi borrow pit ke lokasi fill

a. $\mathrm{xB1}=$ volume pendistribusian tanah dari borrow pit ke lokasi $1\left(\mathrm{~m}^{3}\right)$

b. $\mathrm{xB} 2=$ volume pendistribusian tanah dari borrow pit ke lokasi $2\left(\mathrm{~m}^{3}\right)$

c. $\mathrm{xB} 3=$ volume pendistribusian tanah dari borrow pit ke lokasi $3\left(\mathrm{~m}^{3}\right)$

d. $\mathrm{xB} 4=$ volume pendistribusian tanah dari borrow pit ke lokasi $4\left(\mathrm{~m}^{3}\right)$

e. $\mathrm{xB} 5=$ volume pendistribusian tanah dari borrow pit ke lokasi $5\left(\mathrm{~m}^{3}\right)$

f. $x B 6=$ volume pendistribusian tanah dari borrow pit ke lokasi $6\left(\mathrm{~m}^{3}\right)$

g. $\mathrm{xB} 8=$ volume pendistribusian tanah dari borrow pit ke lokasi $8\left(\mathrm{~m}^{3}\right)$

h. $\mathrm{xB} 11=$ volume pendistribusian tanah dari borrow pit ke lokasi $11\left(\mathrm{~m}^{3}\right)$

i. $\mathrm{xB} 13=$ volume pendistribusian tanah dari borrow pit ke lokasi $13\left(\mathrm{~m}^{3}\right)$

j. $\mathrm{xB} 15=$ volume pendistribusian tanah dari borrow pit ke lokasi $15\left(\mathrm{~m}^{3}\right)$

k. $x$ B18 $=$ volume pendistribusian tanah dari borrow pit ke lokasi $18\left(\mathrm{~m}^{3}\right)$

1. $\mathrm{xB} 20=$ volume pendistribusian tanah dari borrow pit ke lokasi $20\left(\mathrm{~m}^{3}\right)$

m. $\mathrm{xB} 21=$ volume pendistribusian tanah dari borrow pit ke lokasi $21\left(\mathrm{~m}^{3}\right)$

n. $x$ B23 = volume pendistribusian tanah dari borrow pit ke lokasi $23\left(\mathrm{~m}^{3}\right)$

o. $\mathrm{xB} 24=$ volume pendistribusian tanah dari borrow pit ke lokasi $24\left(\mathrm{~m}^{3}\right)$

p. $\times$ B26 $=$ volume pendistribusian tanah dari borrow pit ke lokasi $26\left(\mathrm{~m}^{3}\right)$

q. $\times$ B27 $=$ volume pendistribusian tanah dari borrow pit ke lokasi $27\left(\mathrm{~m}^{3}\right)$

r. $\mathrm{xB} 29=$ volume pendistribusian tanah dari borrow pit ke lokasi $29\left(\mathrm{~m}^{3}\right)$

s. $\mathrm{xB} 30=$ volume pendistribusian tanah dari borrow pit ke lokasi $30\left(\mathrm{~m}^{3}\right)$

t. $\mathrm{xB} 31=$ volume pendistribusian tanah dari borrow pit ke lokasi $31\left(\mathrm{~m}^{3}\right)$

u. $\mathrm{xB} 33=$ volume pendistribusian tanah dari borrow pit ke lokasi $33\left(\mathrm{~m}^{3}\right)$

v. xB34 = volume pendistribusian tanah dari borrow pit ke lokasi $34\left(\mathrm{~m}^{3}\right)$

2. Objective Function

Objective Function dari penelitian ini adalah untuk meminimalkan biaya pendistribusian tanah dengan memperhitungkan biaya satuan dari pekerjaan excavation termasuk loading, biaya satuan dari pekerjaan hauling, dan biaya satuan dari pekerjaan embankment termasuk placement dan compaction, serta memperhitungkan biaya pembelian tanah sebesar Rp 75.000, - .

Minimize $\mathrm{Z}=20000 * \mathrm{x}(9,1)+19500 * \mathrm{x}(9,2)+18500 * \mathrm{x}(9,3)+18000 * \mathrm{x}(9,4)+17000 * \mathrm{x}(9,5)+$ $16500 * x(9,6)+15500 * x(9,8)+15500 * x(9,11)+16000 * x(9,13)+16500 * x(9,15)+18000 * x(9,18)+$ $18500 * x(9,20)+19500 * x(9,21)+20000 * x(9,23)+20500 * x(9,24)+21500 * x(9,26)+22000 * x(9,27)+$ $23000 * \mathrm{x}(9,29)+24000 * \mathrm{x}(9,30)+24500 * \mathrm{x}(9,31)+25500 * \mathrm{x}(9,33)+26000 * \mathrm{x}(9,34)+18000 * \mathrm{x}(9, \mathrm{~K} 1)+$ $17000 * x(9, \mathrm{~K} 2)+22000 * x(9, \mathrm{~K} 3)+21000 * x(14,1)+20500 * x(14,2)+19500 * x(14,3)+19000 * x(14,4)$ $+18500 * x(14,5)+18000 * x(14,6)+16500 * x(14,8)+15500 * x(14,11)+15000 * x(14,13)+15000 * x(14,15)$ $+16500 * x(14,18)+17500 * x(14,20)+18000 * x(14,21)+19000 * x(14,23)+19500 * x(14,24)+$ $20500 * x(14,26)+21000 * x(14,27)+22000 * x(14,29)+22500 * x(14,30)+23000 * x(14,31)+$ $24500 * x(14,33)+25000 * x(14,34)+19500 * x(14, \mathrm{~K} 1)+15500 * x(14, \mathrm{~K} 2)+21000 * \mathrm{x}(14, \mathrm{~K} 3)+$ $21500 * x(16,1)+21000 * x(16,2)+20000 * x(16,3)+19500 * x(16,4)+19000 * x(16,5)+18500 * x(16,6)+$ $17000 * x(16,8)+16000 * x(16,11)+15500 * x(16,13)+15500 * x(16,15)+16000 * x(16,18)+17000 * x(16,20)$ $+17500 * x(16,21)+18500 * x(16,23)+19000 * x(16,24)+20000 * x(16,26)+20500 * x(16,27)+$ $21500 * x(16,29)+22000 * x(16,30)+22500 * x(16,31)+24000 * x(16,33)+24500 * x(16,34)+$ $20000 * \mathrm{x}(16, \mathrm{~K} 1)+16000 * \mathrm{x}(16, \mathrm{~K} 2)+20500 * \mathrm{x}(16, \mathrm{~K} 3)+22000 * \mathrm{x}(17,1)+21500 * \mathrm{x}(17,2)+$ $21000 * x(17,3)+20000 * x(17,4)+19500 * x(17,5)+19000 * x(17,6)+18000 * x(17,8)+16500 * x(17,11)+$ $16500 * x(17,13)+16000 * x(17,15)+15500 * x(17,18)+15500 * x(17,20)+17000 * x(17,21)+$ $18000 * \mathrm{x}(17,23)+18000 * \mathrm{x}(17,24)+19500 * \mathrm{x}(17,26)+19500 * \mathrm{x}(17,27)+20500 * \mathrm{x}(17,29)+$ 
$21500 * x(17,30)+22000 * x(17,31)+23000 * x(17,33)+23500 * x(17,34)+20500 * x(17, \mathrm{~K} 1)+$ $16500 * \mathrm{x}(17, \mathrm{~K} 2)+19500 * \mathrm{x}(17, \mathrm{~K} 3)+24500 * \mathrm{x}(22,1)+24000 * \mathrm{x}(22,2)+23500 * \mathrm{x}(22,3)+22500 * \mathrm{x}(22,4)+$ $22000 * x(22,5)+21500 * x(22,6)+20500 * x(22,8)+19500 * x(22,11)+19000 * x(22,13)+18500 * x(22,15)+$ $17000 * \mathrm{x}(22,18)+16000 * \mathrm{x}(22,20)+15500 * \mathrm{x}(22,21)+15500 * \mathrm{x}(22,23)+16000 * \mathrm{x}(22,24)+$ $17000 * \mathrm{x}(22,26)+17500 * \mathrm{x}(22,27)+18000 * \mathrm{x}(22,29)+19000 * \mathrm{x}(22,30)+19500 * \mathrm{x}(22,31)+$ $21000 * \mathrm{x}(22,33)+21500 * \mathrm{x}(22,34)+23000 * \mathrm{x}(22, \mathrm{~K} 1)+19000 * \mathrm{x}(22, \mathrm{~K} 2)+17000 * \mathrm{x}(22, \mathrm{~K} 3)+$ $27500 * x(28,1)+26500 * x(28,2)+26000 * x(28,3)+25500 * x(28,4)+24500 * x(28,5)+24000 * x(28,6)+$ $23000 * x(28,8)+22000 * x(28,11)+21500 * x(28,13)+21000 * x(28,15)+19500 * x(28,18)+19000 * x(28,20)$ $+18000 * x(28,21)+17500 * x(28,23)+17000 * x(28,24)+16000 * x(28,26)+15500 * x(28,27)+$ $16000 * x(28,29)+16500 * x(28,30)+17000 * x(28,31)+18500 * x(28,33)+19000 * x(28,34)+$ $25500 * \mathrm{x}(28, \mathrm{~K} 1)+21500 * \mathrm{x}(28, \mathrm{~K} 2)+16500 * \mathrm{x}(28, \mathrm{~K} 3)+29500 * \mathrm{x}(32,1)+28500 * \mathrm{x}(32,2)+$ $28000 * x(32,3)+27500 * x(32,4)+26500 * x(32,5)+26000 * x(32,6)+25000 * x(32,8)+24000 * x(32,11)+$ $23500 * \mathrm{x}(32,13)+23000 * \mathrm{x}(32,15)+21500 * \mathrm{x}(32,18)+21000 * \mathrm{x}(32,20)+20000 * \mathrm{x}(32,21)+$ $19500 * x(32,23)+19000 * x(32,24)+18000 * x(32,26)+17500 * x(32,27)+17000 * x(32,29)+$ $16000 * \mathrm{x}(32,30)+15500 * \mathrm{x}(32,31)+16000 * \mathrm{x}(32,33)+16000 * \mathrm{x}(32,34)+28000 * \mathrm{x}(32, \mathrm{~K} 1)+$ $24000 * x(32, \mathrm{~K} 2)+18500 * \mathrm{x}(32, \mathrm{~K} 3)+17000 * \mathrm{xD} 7 \mathrm{~K} 1+18000 * \mathrm{xD} 7 \mathrm{~K} 2+23000 * \mathrm{xD} 7 \mathrm{~K} 3+18500 * \mathrm{xD} 10 \mathrm{~K} 1$ $+16500 * x D 10 \mathrm{~K} 2+21500 * \mathrm{xD} 10 \mathrm{~K} 3+19000 * \mathrm{xD} 12 \mathrm{~K} 1+16000 * \mathrm{xD} 12 \mathrm{~K} 2+21500 * \mathrm{xD} 12 \mathrm{~K} 3+$ $21500 * x D 19 K 1+17500 * x D 19 K 2+19000 * x D 19 K 3+24000 * x D 25 K 1+20000 * x D 25 K 2+16000 * x D 25 K 3$ $+75000 * \mathrm{xB} 1+75000 * \mathrm{xB} 2+75000 * \mathrm{xB} 3+75000 * \mathrm{xB} 4+75000 * \mathrm{xB} 5+75000 * \mathrm{xB} 6+75000 * \mathrm{xB} 8+$ $75000 * x B 11+75000 * x B 13+75000 * x B 15+75000 * x B 18+75000 * x B 20+75000 * x B 21+$ $75000 * x B 23+75000 * x B 24+75000 * x B 26+75000 * x B 27+75000 * x B 29+75000 * x B 30+$ $75000 * x B 31+75000 * x B 33+75000 * x B 34$

3. Constraint

Constraint yang dibutuhkan agar linear programming mendapatkan hasil yang direncanakan adalah sebagai berikut:

Constraint untuk cut

a. $\mathrm{x}(9,1)+\mathrm{x}(9,2)+\mathrm{x}(9,3)+\mathrm{x}(9,4)+\mathrm{x}(9,5)+\mathrm{x}(9,6)+\mathrm{x}(9,8)+\mathrm{x}(9,11)+\mathrm{x}(9,13)+\mathrm{x}(9,15)+\mathrm{x}(9,18)+$ $x(9,20)+x(9,21)+x(9,23)+x(9,24)+x(9,26)+x(9,27)+x(9,29)+x(9,30)+x(9,31)+x(9,33)+$ $\mathrm{x}(9,34)+\mathrm{x}(9, \mathrm{~K} 1)+\mathrm{x}(9, \mathrm{~K} 2)+\mathrm{x}(9, \mathrm{~K} 3)=411.50$

b. $\mathrm{x}(14,1)+\mathrm{x}(14,2)+\mathrm{x}(14,3)+\mathrm{x}(14,4)+\mathrm{x}(14,5)+\mathrm{x}(14,6)+\mathrm{x}(14,8)+\mathrm{x}(14,11)+\mathrm{x}(14,13)+\mathrm{x}(14,15)+$ $x(14,18)+x(14,20)+x(14,21)+x(14,23)+x(14,24)+x(14,26)+x(14,27)+x(14,29)+x(14,30)+$ $\mathrm{x}(14,31)+\mathrm{x}(14,33)+\mathrm{x}(14,34)+\mathrm{x}(14, \mathrm{~K} 1)+\mathrm{x}(14, \mathrm{~K} 2)+\mathrm{x}(14, \mathrm{~K} 3)=40.50$

c. $\quad \mathrm{x}(16,1)+\mathrm{x}(16,2)+\mathrm{x}(16,3)+\mathrm{x}(16,4)+\mathrm{x}(16,5)+\mathrm{x}(16,6)+\mathrm{x}(16,8)+\mathrm{x}(16,11)+\mathrm{x}(16,13)+\mathrm{x}(16,15)+$ $x(16,18)+x(16,20)+x(16,21)+x(16,23)+x(16,24)+x(16,26)+x(16,27)+x(16,29)+x(16,30)+$ $x(16,31)+x(16,33)+x(16,34)+x(16, K 1)+x(16, K 2)+x(16, K 3)=324.50$

d. $\quad x(17,1)+x(17,2)+x(17,3)+x(17,4)+x(17,5)+x(17,6)+x(17,8)+x(17,11)+x(17,13)+x(17,15)+$ $x(17,18)+x(17,20)+x(17,21)+x(17,23)+x(17,24)+x(17,26)+x(17,27)+x(17,29)+x(17,30)+$ $\mathrm{x}(17,31)+\mathrm{x}(17,33)+\mathrm{x}(17,34)+\mathrm{x}(17, \mathrm{~K} 1)+\mathrm{x}(17, \mathrm{~K} 2)+\mathrm{x}(17, \mathrm{~K} 3)=1746.75$

e. $\mathrm{x}(22,1)+\mathrm{x}(22,2)+\mathrm{x}(22,3)+\mathrm{x}(22,4)+\mathrm{x}(22,5)+\mathrm{x}(22,6)+\mathrm{x}(22,8)+\mathrm{x}(22,11)+\mathrm{x}(22,13)+\mathrm{x}(22,15)+$ $\mathrm{x}(22,18)+\mathrm{x}(22,20)+\mathrm{x}(22,21)+\mathrm{x}(22,23)+\mathrm{x}(22,24)+\mathrm{x}(22,26)+\mathrm{x}(22,27)+\mathrm{x}(22,29)+\mathrm{x}(22,30)+$ $\mathrm{x}(22,31)+\mathrm{x}(22,33)+\mathrm{x}(22,34)+\mathrm{x}(22, \mathrm{~K} 1)+\mathrm{x}(22, \mathrm{~K} 2)+\mathrm{x}(22, \mathrm{~K} 3)=216.50$

f. $\mathrm{x}(28,1)+\mathrm{x}(28,2)+\mathrm{x}(28,3)+\mathrm{x}(28,4)+\mathrm{x}(28,5)+\mathrm{x}(28,6)+\mathrm{x}(28,8)+\mathrm{x}(28,11)+\mathrm{x}(28,13)+\mathrm{x}(28,15)+$ $\mathrm{x}(28,18)+\mathrm{x}(28,20)+\mathrm{x}(28,21)+\mathrm{x}(28,23)+\mathrm{x}(28,24)+\mathrm{x}(28,26)+\mathrm{x}(28,27)+\mathrm{x}(28,29)+\mathrm{x}(28,30)+$ $\mathrm{x}(28,31)+\mathrm{x}(28,33)+\mathrm{x}(28,34)+\mathrm{x}(28, \mathrm{~K} 1)+\mathrm{x}(28, \mathrm{~K} 2)+\mathrm{x}(28, \mathrm{~K} 3)=845$

g. $\quad \mathrm{x}(32,1)+\mathrm{x}(32,2)+\mathrm{x}(32,3)+\mathrm{x}(32,4)+\mathrm{x}(32,5)+\mathrm{x}(32,6)+\mathrm{x}(32,8)+\mathrm{x}(32,11)+\mathrm{x}(32,13)+\mathrm{x}(32,15)+$ $\mathrm{x}(32,18)+\mathrm{x}(32,20)+\mathrm{x}(32,21)+\mathrm{x}(32,23)+\mathrm{x}(32,24)+\mathrm{x}(32,26)+\mathrm{x}(32,27)+\mathrm{x}(32,29)+\mathrm{x}(32,30)+$ $\mathrm{x}(32,31)+\mathrm{x}(32,33)+\mathrm{x}(32,34)+\mathrm{x}(32, \mathrm{~K} 1)+\mathrm{x}(32, \mathrm{~K} 2)+\mathrm{x}(32, \mathrm{~K} 3)=2250$

Constraint untuk fill

a. $\quad 0.8 * \mathrm{x}(9,1)+0.8 * \mathrm{x}(14,1)+0.8 * \mathrm{x}(16,1)+0.8 * \mathrm{x}(17,1)+0.8 * \mathrm{x}(22,1)+0.8 * \mathrm{x}(28,1)+0.8^{*} \mathrm{x}(32,1)+$ $0.9 * \times B 1=527.25$

b. $\quad 0.8 * x(9,2)+0.8 * x(14,2)+0.8 * x(16,2)+0.8 * x(17,2)+0.8 * x(22,2)+0.8 * x(28,2)+0.8 * x(32,2)+$ $0.9 * \times B=492.75$

c. $\quad 0.8 * \mathrm{x}(9,3)+0.8 * \mathrm{x}(14,3)+0.8 * \mathrm{x}(16,3)+0.8 * \mathrm{x}(17,3)+0.8 * \mathrm{x}(22,3)+0.8 * \mathrm{x}(28,3)+0.8^{*} \mathrm{x}(32,3)+$ $0.9 * \times B 3=326.25$

d. $0.8 * \mathrm{x}(9,4)+0.8^{*} \mathrm{x}(14,4)+0.8^{*} \mathrm{x}(16,4)+0.8^{*} \mathrm{x}(17,4)+0.8^{*} \mathrm{x}(22,4)+0.8^{*} \mathrm{x}(28,4)+0.8^{*} \mathrm{x}(32,4)+$ $0.9 * \times B 4=559.75$

e. $\quad 0.8 * x(9,5)+0.8 * x(14,5)+0.8 * x(16,5)+0.8 * x(17,5)+0.8 * x(22,5)+0.8 * x(28,5)+0.8 * x(32,5)+$ $0.9 * \times B 5=475.25$ 


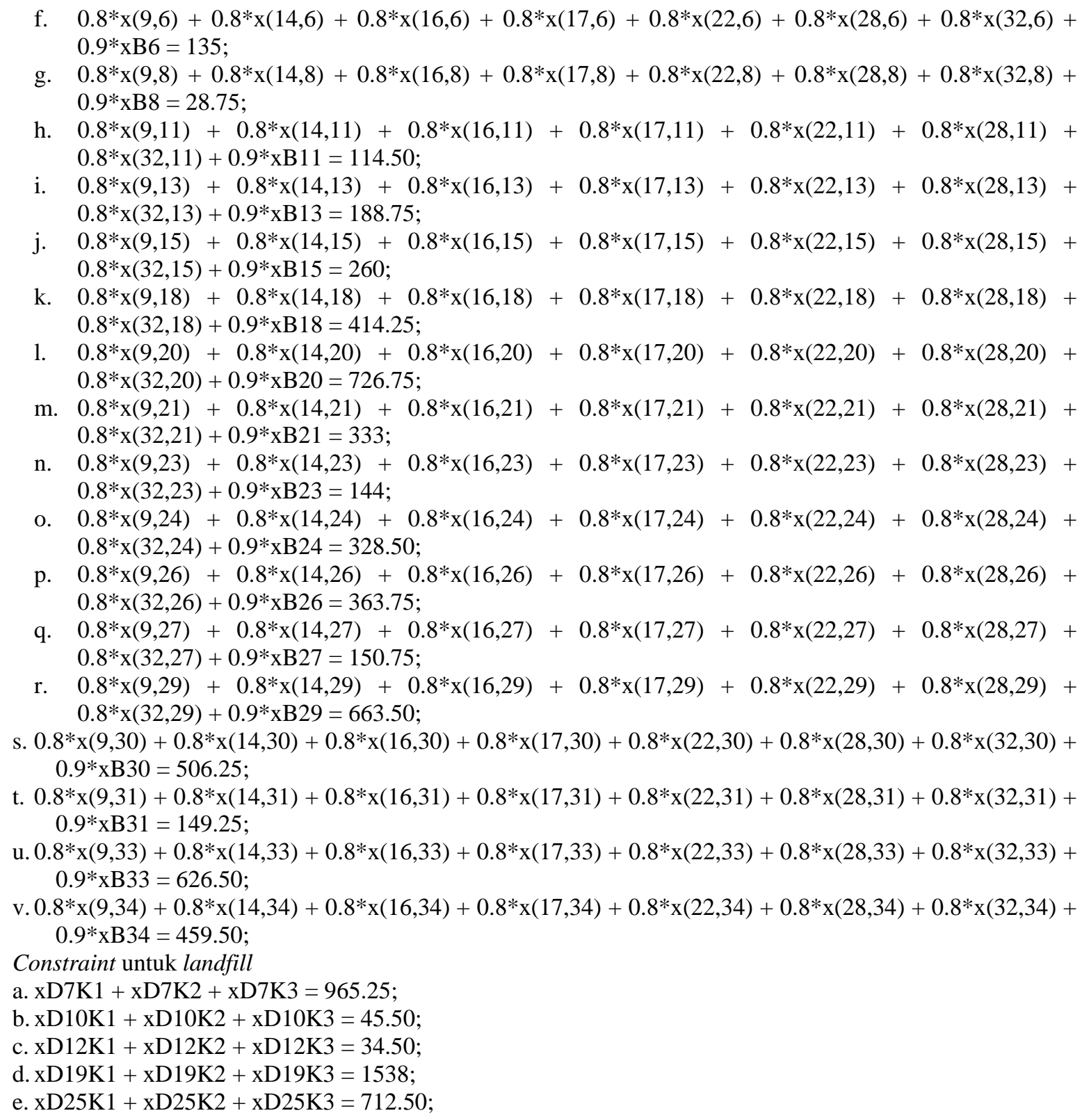

\section{Hasil Nilai Optimasi}

Berdasarkan hasil pengolahan data dengan menggunakan Lingo, maka didapatkan hasil optimasi pendistribusian tanah pada proyek X dengan biaya pendistriibusian tanah sebesar Rp 423.965.100, -. Hasil nilai optimasi yang didapat adalah sebagai berikut:

1. Volume pendistribusian tanah dari lokasi 9 ke lokasi 5 adalah $63,6875 \mathrm{~m}^{3}$

2. Volume pendistribusian tanah dari lokasi 9 ke lokasi 6 adalah $168,750 \mathrm{~m}^{3}$

3. Volume pendistribusian tanah dari lokasi 9 ke lokasi 8 adalah $35,9375 \mathrm{~m}^{3}$

4. Volume pendistribusian tanah dari lokasi 9 ke lokasi 11 adalah $143,125 \mathrm{~m}^{3}$

5. Volume pendistribusian tanah dari lokasi 14 ke lokasi 13 adalah $40,50 \mathrm{~m}^{3}$

6. Volume pendistribusian tanah dari lokasi 16 ke lokasi 13 adalah $195,4375 \mathrm{~m}^{3}$

7. Volume pendistribusian tanah dari lokasi 16 ke lokasi 15 adalah $129,0625 \mathrm{~m}^{3}$

8. Volume pendistribusian tanah dari lokasi 17 ke lokasi 15 adalah $195,9375 \mathrm{~m}^{3}$

9. Volume pendistribusian tanah dari lokasi 17 ke lokasi 18 adalah $517,8125 \mathrm{~m}^{3}$

10. Volume pendistribusian tanah dari lokasi 17 ke lokasi 20 adalah $908,4375 \mathrm{~m}^{3}$

11. Volume pendistribusian tanah dari lokasi 17 ke lokasi 21 adalah $124,5625 \mathrm{~m}^{3}$

12. Volume pendistribusian tanah dari lokasi 22 ke lokasi 21 adalah $36,50 \mathrm{~m}^{3}$

13. Volume pendistribusian tanah dari lokasi 22 ke lokasi 23 adalah $180 \mathrm{~m}^{3}$ 
14. Volume pendistribusian tanah dari lokasi 28 ke lokasi 27 adalah $188,4375 \mathrm{~m}^{3}$

15. Volume pendistribusian tanah dari lokasi 28 ke lokasi 29 adalah $656,5625 \mathrm{~m}^{3}$

16. Volume pendistribusian tanah dari lokasi 32 ke lokasi 29 adalah $73,1250 \mathrm{~m}^{3}$

17. Volume pendistribusian tanah dari lokasi 32 ke lokasi 30 adalah $632,8125 \mathrm{~m}^{3}$

18. Volume pendistribusian tanah dari lokasi 32 ke lokasi 31 adalah $186,5625 \mathrm{~m}^{3}$

19. Volume pendistribusian tanah dari lokasi 32 ke lokasi 33 adalah $783,1250 \mathrm{~m}^{3}$

20. Volume pendistribusian tanah dari lokasi 32 ke lokasi 34 adalah $574,3750 \mathrm{~m}^{3}$

21. Volume pendistribusian tanah dari lokasi 7 ke lokasi $\mathrm{K} 1$ adalah $965,250 \mathrm{~m}^{3}$

22. Volume pendistribusian tanah dari lokasi $10 \mathrm{ke}$ lokasi $\mathrm{K} 2$ adalah $45,50 \mathrm{~m}^{3}$

23. Volume pendistribusian tanah dari lokasi 12 ke lokasi $\mathrm{K} 2$ adalah $34,50 \mathrm{~m}^{3}$

24. Volume pendistribusian tanah dari lokasi 19 ke lokasi $\mathrm{K} 2$ adalah $1538 \mathrm{~m}^{3}$

25. Volume pendistribusian tanah dari lokasi 25 ke lokasi $\mathrm{K} 3$ adalah $712,50 \mathrm{~m}^{3}$

26. Volume pendistribusian tanah dari lokasi borrow pit ke lokasi 1 adalah $585,8333 \mathrm{~m}^{3}$

27. Volume pendistribusian tanah dari lokasi borrow pit ke lokasi 2 adalah $547,500 \mathrm{~m}^{3}$

28. Volume pendistribusian tanah dari lokasi borrow pit ke lokasi 3 adalah $362,500 \mathrm{~m}^{3}$

29. Volume pendistribusian tanah dari lokasi borrow pit ke lokasi 4 adalah $621,9444 \mathrm{~m}^{3}$

30. Volume pendistribusian tanah dari lokasi borrow pit ke lokasi 5 adalah $471,4444 \mathrm{~m}^{3}$

31. Volume pendistribusian tanah dari lokasi borrow pit ke lokasi 21 adalah $226,8333 \mathrm{~m}^{3}$

32. Volume pendistribusian tanah dari lokasi borrow pit ke lokasi 24 adalah $365.00 \mathrm{~m}^{3}$

33. Volume pendistribusian tanah dari lokasi borrow pit ke lokasi 26 adalah $404,1667 \mathrm{~m}^{3}$

34. Volume pendistribusian tanah dari lokasi borrow pit ke lokasi 29 adalah $88,6111 \mathrm{~m}^{3}$

Keterangan: variable yang tidak ada berarti bernilai 0

\section{KESIMPULAN}

Dalam penelitian ini, kesimpulan yang dapat diambil adalah sebagai berikut:

1. Hasil biaya pendistribusian tanah yang didapat setelah dilakukan optimasi dengan menggunakan linear programming adalah sebesar $\mathrm{Rp} 423.965 .100$, - dengan pendistribusian tanah sebagai berikut:

a. Dari lokasi 9 ke lokasi 5, 6, 8, dan 11

b. Dari lokasi 14 ke 13

c. Dari lokasi 16 ke 13 dan 15

d. Dari lokasi 17 ke 15, 18, 20, dan 21

e. Dari lokasi 22 ke 21 dan 23

f. Dari lokasi 28 ke 27 dan 29

g. Dari lokasi 32 ke 29, 30, 31, 33, dan 34

h. Dari lokasi 7 ke K1, 10 ke K2, 12 ke K2, 19 ke K2, dan 25 ke K3

i. Dari borrow pit ke lokasi 1, 2, 3, 4, 5, 21, 24, 26, dan 29

2. Pada hasil optimasi volume pendistribusian tanah, dapat dilihat bahwa untuk menghasilkan biaya pendistribusian tanah yang minimum maka tanah pada lokasi cut didistribusikan ke lokasi fill yang dekat. Sedangkan untuk lokasi fill yang letaknya jauh terhadap lokasi cut menerima tanah dari borrow pit. Jika tanah pada lokasi cut tersebut tidak didistribusi ke lokasi fill yang dekat tetapi ke lokasi fill yang jauh, tanah pada lokasi fill yang dekat akan menerima tanah dari borrow pit maka biaya pendistribusian tanah akan menjadi lebih mahal.

3. Pada hasil optimasi volume pendistribusian tanah, ada beberapa decision variabel yang bernilai 0 . Hal ini disebabkan karena tanah pada lokasi cut yang akan didistribusikan ke lokasi fill tersebut sudah habis terdistribusi ke lokasi fill yang lain. Tanah pada lokasi fill tersebut nantinya akan menerima tanah dari lokasi cut yang lain atau menerima tanah dari borrow pit.

\section{DAFTAR PUSTAKA}

Bowles, E.J. 1989. Sifat-sifat Fisis dan Geoteknis Tanah. Erlangga. Jakarta.

Chase, R.B. Aquilano, N.J. and Jacobs, F.R. 2001. Operations Management for Competitive Advantage. McGrawHill Irwin. New York.

Das, Braja M. 1995. Mekanika Tanah 1. Erlangga. Jakarta.

Mayer, R.H and Stark, R.M. 1981. Earthmoving Logistics. Journal of the Construction Division, Vol. 107, Issue 2.

Rochmanhadi. 1990. Pengantar dan Dasar - Dasar Pemindahan Tanah Mekanis. Departemen Pekerjaan Umum. Jakarta.

Rochmanhadi. 1992. Alat - Alat Berat dan Penggunaannya. Yayasan Badan Penerbit Pekerjaan Umum. Jakarta.

Todd, M.J. 2002. The Many Facets of Linear Programming. Journal of Mathematical Programming, Vol. 91. Cornell University. New York. 